\title{
Systems of innovation and the adoption of biotechnologies: the case of Mexico
}

\author{
Julieta Flores-Amador \\ Canada Research Chair on Management of Technology, \\ B.P. 8888 Succursale Centre-Ville, \\ Montréal, Québec, H3C 3P8, Canada \\ E-mail: flores_amador.julieta@courrier.uqam.ca \\ E-mail: floresamador_julieta@hotmail.com
}

\begin{abstract}
Developed countries have been adopting modern biotechnologies relying on innovation systems that nurture the financial, technological and specialised human resources needed to achieve innovations, especially in human health biotechnologies (Niosi et al., 2005; Cockburn and Stern, 2010). In the last two decades, some emerging countries have attempted to adopt modern biotechnologies in their industries. However, these countries face unstructured institutional frameworks that affect their innovation systems (Niosi and Reid, 2007); still few innovations have been developed and some local firms have incorporated modern biotechnologies into their productions processes (Nature Biotechnology, 2004). Under these circumstances, a general question is raised: what are the characteristics of the firms adopting biotechnologies in emerging countries? In order to answer this question I take the case of Mexico. Two types of firms adopting biotechnologies were identified, only those, that have developed absorptive capabilities, have benefited from both national and international partners.
\end{abstract}

Keywords: biotechnology firms; emerging countries; Mexico; collaborations; systems of innovation.

Reference to this paper should be made as follows: Flores-Amador, J. (2014) 'Systems of innovation and the adoption of biotechnologies: the case of Mexico', Int. J. Biotechnology, Vol. 13, Nos. 1/2/3, pp.120-136.

Biographical notes: Julieta Flores-Amador received her $\mathrm{PhD}$ in Business Administration at Université du Québec à Montréal (Canada). Her dissertation was focused on the adoption of biotechnologies in Mexico. She has presented research findings at international conferences and peer-reviewed refereed journals. Her research interests include technology management, innovation systems, and intellectual property strategies. She received her BSc in Economics and MSc in Economics and Technology Management from Universidad Autónoma Metropolitana (Mexico).

\section{Introduction}

Biotechnology involves a group of technologies based on different scientific fields (i.e., genetic engineering, bioleaching, biopulping, bioinformatics, and other) that are used in different industries, and based on advances of sciences (i.e., biology, biochemistry, genetics) of the last 60 years ${ }^{1}$. Given the wide and multidisciplinary knowledge base of biotechnologies, countries aiming to encourage the adoption of these 
technologies often have implemented policies to support the creation of organisations and institutions that facilitate and nurture the generation of knowledge, the creation of new and specialised markets, and the translation from scientific results to commercial products. For example, countries like the USA and England have consolidated the adoption $^{2}$ of modern biotechnologies in industrial processes and have commercialised biotechnology products such as bio-drugs, based heavily on their systems of innovation at different levels (national, regional and sectoral) (Niosi et al., 2005; Cooke, 2007; Cockburn and Stern, 2010).

In the last decades, some emerging ${ }^{3}$ countries have implemented scientific and technology (S\&T) policies to promote the adoption of modern biotechnologies. However, only in few cases - e.g., China and Singapore - the efforts to create a favourable institutional framework ${ }^{4}$ to adopt biotechnologies have been successful. Still, firms in emerging countries do adopt modern biotechnologies. In this sense, it is relevant to know what are the characteristics of the firms adopting biotechnologies under the conditions present in emerging countries? In order to shed light about this subject I take the case of Mexico. Although this country is seen as a potential pharmaceutical and agricultural market $^{5}$, little is known about the actions and agents taking part in the adoption of biotechnologies. Some authors have analysed the process of collaboration between different agents (Casas et al., 2000; Bolivar et al., 2002), and the development of biotechnology human resources (Corona, 2006) in the Mexican context. These studies underline the role of universities and research centres to generate new knowledge and the mechanisms to establish linkages with producers to transfer this knowledge. This document is focused on the analysis of firms, their characteristics and how they collaborate with other organisations to adopt biotechnologies.

The remainder of this document is organised as follows: in Section 2 the theoretical framework is presented. Section 3 presents the research questions. Section 4 deals with the data collection. The results of this study are presented in Section 5. Finally, Section 6 concludes.

\section{Theoretical framework}

Given the multidisciplinary knowledge base of biotechnologies and the importance of institutional frameworks and collaborations in high technology products, the systems of innovation and networks of learning concepts are used to analyse the adoption of biotechnologies.

\subsection{System of innovation}

The concept of national system of innovation (NSI) appeared in the mid-1980s as a tool to design and implement industrial policies in Europe (Sharif, 2006). Since then, it has been used in both academia and policy-making fields to identify and analyse interactions between different agents in order to design adequate policies to support innovation (Sharif, 2006; Nelson, 2000). Consequently, the main objective of NSI, as analytical framework, is to identify the main agents involved in the innovation process as well as to procure an institutional framework to enable the collaboration and interaction between those agents through public policies (Nelson, 1993; Lundvall, 1992). 
Systems of innovation are influenced by particular local conditions (social, political and economic), at different levels of analysis (local, regional or national) and economic activities (sector) (Sharif, 2006; Nelson, 2000). Since the 1990s, the concept of regional system of innovation (RSI) has gained relevance. This concept underlines regional characteristics, which differ according to their resources endowment and size (in terms of market size) (Nelson 2000), and identifies the relationships between agents in that region (Cooke and Morgan, 1998). At least three main groups of agents are involved in systems of innovation: firms, universities, and governments (including government agencies and public policies) (Nelson, 2000). Additionally, other kind of organisations like associations, information suppliers, venture capital firms, linkage facilitators, and technological consultancy are important to leverage the creation of innovations (Niosi, 2010). All these agents are interrelated through relationships that vary according to the sector and government support. For this reason, the identification of the kinds of linkages, scope of objectives, and type of agents involved in these interrelations allows a better understanding of the adoption and development of new technologies.

\subsection{Networks of learning approach}

The concept of network is related to the relationships between different agents in a determined context. In the case of production activities, a network is a form of coordinating economic activity and a form of governance that allows collaboration between different agents facilitating the exchange of information, the access to valuable assets (knowledge, know-how), and the risk sharing (Powell, 1990; Smith-Doerr and Powell, 2005).

Networks, also, have an important impact on learning and innovation processes, especially in high technologies, which require a variety of resources and assets: specialised knowledge ${ }^{6}$, technological and managerial capabilities, and large investments. Since no single firm owns all the resources needed for the creation, production, and marketing of new high technology products, and because the amount of available useful new knowledge increases exponentially, firms often collaborate with other organisations (e.g., other firms, government agencies, universities) in order to obtain complementary knowledge, resources, and capabilities (Teece et al., 1997; Powell et al., 1996; Oliver, 2001). Collaboration between different organisations allows individuals, and in turn organisations, to be aware of other activities or projects that could improve their performance. Therefore, external sources of knowledge are important for innovation. In order to completely adopt external knowledge, firms have to possess absorptive capacity to identify, assimilate and exploit external knowledge (Cohen and Levinthal, 1990; Zahra and George, 2002). Consequently, organisations in networks have to share basic skills that allow them to communicate and translate technical and scientific developments (Oliver, 2001). Accordingly, networks of learning make possible the diffusion of knowledge, the interfirm learning and the exploration of complementarities among organisations [Pyka and Saviotti, (2000), p.15].

\subsection{System of innovation and learning networks in biotechnology}

Empirical research in developed countries has shown that governments play an important role in the adoption and diffusion of biotechnologies. Governments often implement policies that promotes incentives to push forward scientific advances related to 
biotechnology and the adoption and diffusion of those novelties: providing grants and public funds dedicated to basic science, establishing technological parks and incubators, facilitating relationships between private and public organisations (e.g., firms and research centres), supporting the establishment of new enterprises, and promoting incentives to innovate (Cockburn and Stern, 2010; Niosi, 2010).

As mentioned before, the development and commercialisation of biotechnology products require a network of different organisations and institutions (see Table 1): knowledge-creating organisations are critical for the scientific progress as well as for training specialised human resources; biotechnology enterprises (large and small enterprises) develop and commercialise biotechnology products; funding organisations are also important players given the large investments that modern biotechnologies require. The interaction between these organisations often is encouraged by science, technology, and innovation policies that support the adoption and diffusion of biotechnologies: for example, governments often provide funds for scientific research, establish intellectual property laws that encourage innovation, and promote collaborations to create and/or acquire diverse resources such as tacit and codified knowledge, financial resources, specialised inputs and management guidance (Kenney, 1986; Niosi et al., 2005).

Table 1 Main organisations and institutions supporting the adoption of biotechnologies

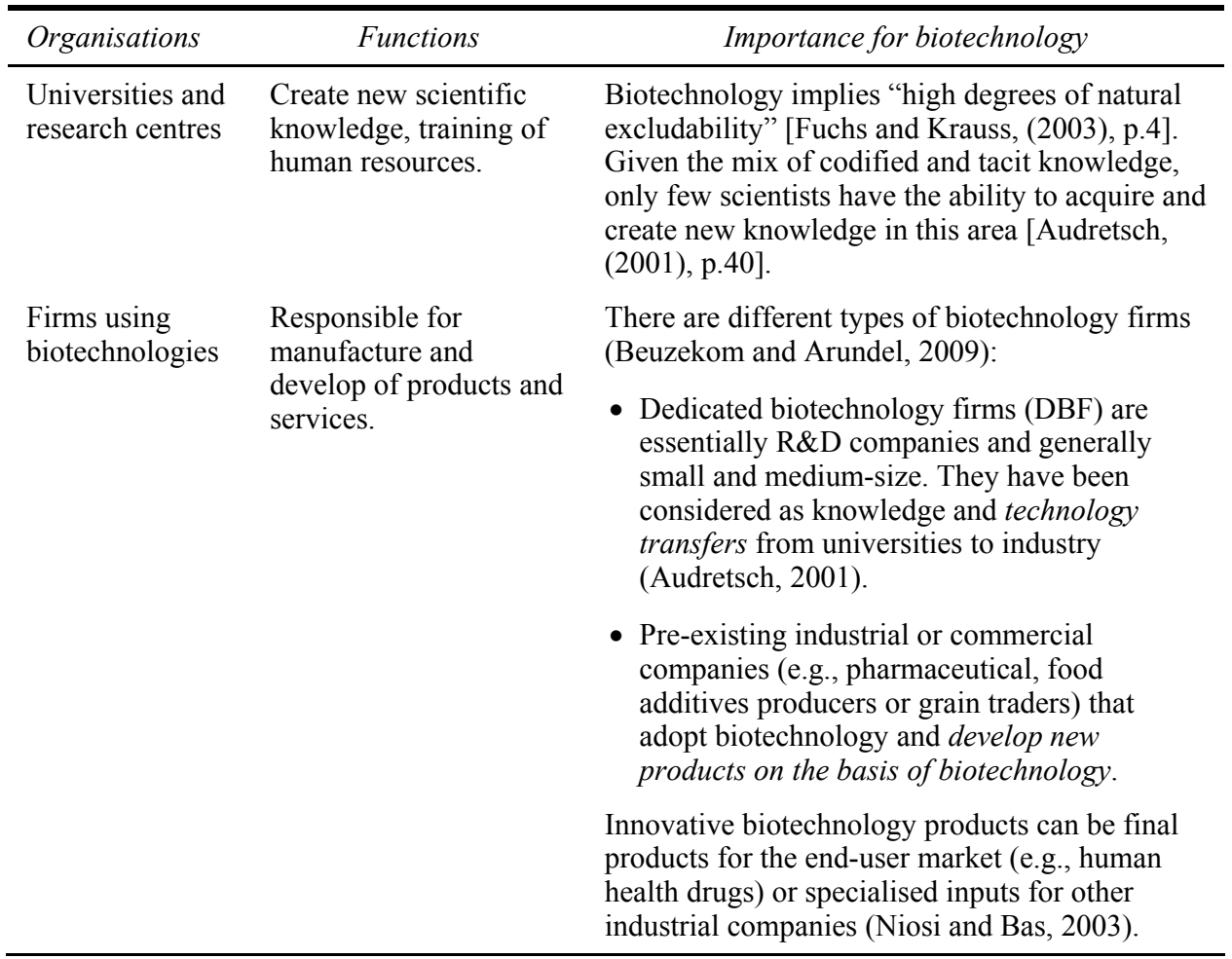

Note: ${ }^{1}$ Institutions involve the rules, norms and laws established in order to improve the competitiveness of the firms that create, adopt, and commercialise biotechnologyrelated products and help to avoid uncertainty and risk [North, (1990), pp.3-10; Pisano, 2006). 
Table 1 Main organisations and institutions supporting the adoption of biotechnologies (continued)

\begin{tabular}{|c|c|c|}
\hline Organisations & Functions & Importance for biotechnology \\
\hline $\begin{array}{l}\text { Funding } \\
\text { organisations }\end{array}$ & $\begin{array}{l}\text { Public and private } \\
\text { organisations provide } \\
\text { funds at different stages } \\
\text { for the generation of } \\
\text { new products, from } \\
\text { supporting basic } \\
\text { scientific research } \\
\text { through establishment } \\
\text { of firms to } \\
\text { commercialisation of } \\
\text { final products or } \\
\text { licenses. }\end{array}$ & $\begin{array}{l}\text { Translating scientific results (from } \\
\text { biotechnology areas) into commercial products } \\
\text { requires huge investments. As a DBF evolves, it } \\
\text { requires more research personnel, sophisticated } \\
\text { inputs, and larger facilities, thus venture capital, } \\
\text { alliances and stock markets provide the financial } \\
\text { resources (Pisano, 2006; Cooke, 2007). }\end{array}$ \\
\hline Institutions $^{1}$ & Functions & Importance for biotechnology \\
\hline $\begin{array}{l}\text { R\&D } \\
\text { investments }\end{array}$ & $\begin{array}{l}\text { Government } \\
\text { investments to promote } \\
\text { and support scientific } \\
\text { activities and create and } \\
\text { revamp knowledge- } \\
\text { creating organisations. }\end{array}$ & $\begin{array}{l}\text { The scientific advances of the different } \\
\text { disciplines related to biotechnologies require } \\
\text { large investments that facilitate the access to } \\
\text { highly qualified human resources, specialised } \\
\text { inputs and sophisticated equipment (Chiaroni } \\
\text { and Chiesa, 2006). }\end{array}$ \\
\hline $\begin{array}{l}\text { Intellectual } \\
\text { property rights } \\
\text { (IPR) }\end{array}$ & $\begin{array}{l}\text { Government } \\
\text { organisations define the } \\
\text { intellectual property } \\
\text { regulations within a } \\
\text { country or region. }\end{array}$ & $\begin{array}{l}\text { Patents can be seen as incentives to push forward } \\
\text { the establishment of new biotechnology firms } \\
\text { and to attract private investors (e.g., VC, private } \\
\text { equity, and large companies) (Zucker et al., } \\
\text { 1998). }\end{array}$ \\
\hline Networking & $\begin{array}{l}\text { Governments often } \\
\text { establish institutional } \\
\text { frameworks to enable } \\
\text { and encourage formal } \\
\text { and informal } \\
\text { collaborations between } \\
\text { different actors (public } \\
\text { or private) to } \\
\text { complement resources } \\
\text { and capabilities. }\end{array}$ & $\begin{array}{l}\text { The generation of scientific knowledge requires } \\
\text { a constant flow of information and face-to-face } \\
\text { feedbacks among scientists, which can be seen as } \\
\text { informal or } \\
\text { non-contractual collaboration (Cooke, 2007). } \\
\text { Formal collaborations are exemplified by } \\
\text { alliances and research contracts (Rothaermel and } \\
\text { Deeds, 2004; Pichaud, 2002). }\end{array}$ \\
\hline
\end{tabular}

Note: ${ }^{1}$ Institutions involve the rules, norms and laws established in order to improve the competitiveness of the firms that create, adopt, and commercialise biotechnologyrelated products and help to avoid uncertainty and risk [North, (1990), pp.3-10; Pisano, 2006).

\subsection{Biotechnology in emerging countries}

Since the 1980s some emerging countries have implemented policies to promote the adoption of modern biotechnologies by their local enterprises (Nature Biotechnology, 2004; Cooke, 2007). The adoption of biotechnologies in these countries varies according to their socioeconomic contexts and government intervention. These countries face, at different levels, limited access to financial resources, highly qualified human resources and sophisticated equipment. These facts have implications in the manner research centres and enterprises develop and adopt biotechnologies, especially the more complex 
ones (e.g., DNA codification). Among emerging countries, particular attention has been paid to the cases of China and India given their potential to become important players in the global market of biotechnology products such as biopharmaceuticals and bio-agriculture (Nature Biotechnology, 2010a, 2010b). In both countries the active involvement of their governments has created a favourable environment for adopting biotechnologies throughout the implementation of policies and programmes - from improving education, training and infrastructure, passing through modernisation of local industries, to the creation of venture capital industries, and lure MNC to establish alliances (Nature, 2005; Niosi and Reid, 2007; Prevezer, 2008; Nature Biotechnology, 2010a, 2010b). Other emerging countries have attempted to develop biotechnology products and services. For instance, some efforts have been documented in Argentina, Brazil, Chile, Mexico, South Africa, South Korea, and Turkey (Bolivar et al., 2002; Nature Biotechnology, 2004; Buckley et al., 2006). However, the large investments and complexity of modern biotechnologies seem to set barriers for their adoption (Niosi and Reid, 2007; Fan, 2011; Wolson, 2007). In consequence, firms in these countries have developed particular ways to adopt biotechnologies.

\section{Research questions}

As mentioned before, the adoption of biotechnologies requires a favourable institutional framework in which organisations and institutions can be articulated through networks of learning. Some authors have analysed the adoption of biotechnologies in Mexico and how the university-industry-government linkages work to achieve biotechnology products (Casas et al., 2000; Bolivar et al., 2002), and the formation of biotechnology human resources (Corona, 2006). Mexico has developed an unstructured national system of innovation (Cimoli, 2000; Dutrénit et al., 2010), which faces the lack of key players for the development of biotechnologies (e.g., venture capital). However, there are some regions, in which organisations and institutions have accumulated capabilities that allow them to establish linkages between them and achieve the adoption of biotechnologies (Casas et al., 2000). In addition, the Mexican government has made some efforts to define strategic sectors and strengthen the linkages between organisations to innovate 7 . The objective of this document is to understand how firms adopt modern biotechnologies in emerging countries like Mexico. Therefore, the unit of analysis is the firm:

- What are the characteristics of firms adopting biotechnologies in Mexico?

- What are the motives for collaboration? Who are the collaborators?

\section{Data collection}

Given that little is known about the use of biotechnologies in Mexico, this is an exploratory study. As such, the collection of data was carried out in two phases. The first phase included the review of secondary sources to identify the agents of the Mexican NSI involved in biotechnology activities. Once the identification of these agents was achieved, interviews were conducted to better understand how firms pursue biotechnology activities. Data was collected from face-to-face interviews with sixteen 
managers of biotechnology enterprises located in the central region of Mexico: Mexico City, Morelos and State of Mexico ${ }^{8}$ (Table 2). The interviews were based on a questionnaire ${ }^{9}$ that includes subjects about the characteristics of firms, capabilities, collaborations, funding, institutional support, and strategies.

Table 2 Distribution of biotechnology enterprises in Mexico

\begin{tabular}{lc}
\hline States & Number of enterprises \\
\hline Mexico City & 19 \\
State of Mexico & 12 \\
Jalisco & 5 \\
Chihuahua & 3 \\
Morelos & 3 \\
Nuevo León & 3 \\
Queretaro & 3 \\
Sinaloa & 3 \\
Coahuila & 2 \\
Aguascalientes & 1 \\
Baja California & 1 \\
Colima & 1 \\
Michoacán & 1 \\
Puebla & 1 \\
Total & 58 \\
\hline
\end{tabular}

Source: Own search

\section{Biotechnology adoption in Mexico}

\subsection{The national system of innovation of Mexico}

This section presents an overview of the Mexican institutional framework analysing its implications for the adoption of biotechnologies in the country. The Mexican NSI encompasses the following agents (Dutrénit et al., 2010):

- government organisms and institutions (e.g., National Council on Science and Technology (CONACYT), state councils on science and technology (S\&T), and $\mathrm{S} \& \mathrm{~T}$ committees in the legislature

- public research centres (PRC) which are run by different entities

[such as CONACYT, ministries, and higher education institutions (HEI)]

- intermediate institutions (such as foundations and associations)

- innovative enterprises in the private sector

- part of the financial system.

The list of these agents shows that relevant organisations and institutions related to innovation processes are present in the Mexican context, however linkages between them 
are not evident. On the one hand, enterprises in the private sector interact closely with government agencies mainly because some industrial incentives, but they have weak linkages with other important agents such as knowledge-creating organisations (e.g., HEIs or PRCs) and the financial system. On the other hand, public organisations aimed to the advancement of knowledge and training - such as PRCs, HEIs, and CONACYT - have strong linkages between them [Dutrénit et al., (2010), pp.93-94]. In consequence, the Mexican NSI is not well articulated: there is a lack of communication between the industrial and knowledge-creating organisations (Cimoli, 2000; Dutrénit et al., 2010). In order to improve this situation, in the last decade, the Mexican government has implemented some programmes and policies ${ }^{10}$ to foster domestic technology development, emphasise research collaboration, and promote its relevance for enterprises in order to accomplish successful innovative products ${ }^{11}$ (OECD, 2009a). However, the current Mexican context offers few incentives to push private firms to conduct R\&D - by their own or in collaboration - and innovate: there is a lack of financial support, legal frameworks that stimulates the flows of knowledge and leaning; in terms of policies, there are problems to define priority sectors, and assess the pertinence and coordination of technology policies (Charvel, 2007; OECD, 2009a, 2009b). Under these circumstances, it seems that the Mexican institutional framework has generated some incentives to explore new technologies through scientific activities carried out in HEI and PRC, however, the weak institutional framework set some obstacles that hamper the translation from scientific results into commercial products.

\subsection{Systems of innovation for biotechnology: agents and linkages}

This section describes the Mexican organisations and institutions involved in the adoption of biotechnologies: the generation of new scientific knowledge, the incorporation of it into the production system, and the collaboration between different agents.

\subsubsection{Agents}

Universities and research centres: in Mexico, there are around twenty HEI and PRC with highly qualified research groups focused on modern biotechnology and some of these have established linkages with enterprises to transfer technologies (Bolivar et al., 2002; Secretaría de Economía, 2010) (see Table 3). Among these modern biotechnology research centres there are two pioneers: the Biotechnology Institute of the National Autonomous University of Mexico (Ibt-UNAM in Spanish) created in 1982 and established in the state of Morelos, and the Centre for Research and Advances Studies of the National Polytechnic Institute (CINVESTAV-IPN) created in 1981 and established in the state of Guanajuato (Posanni, 2003). In addition, in the early-2000s, other centres were revamped and created to support biotechnology research: in 2003 the University Council at UNAM approved the establishment of the Centre for Genomic Sciences $(C C G)^{12}$ in Morelos and its research groups are focused on issues related to plant genomics, and more recently, on some aspects of human genomics. In 2004 the Congress of the Union passed the initiative to create the National Institute of Genomic Medicine (INMEGEN) as a decentralised public organism and being part of the National Institutes of Health System ${ }^{13}$. In 2005, the National Laboratory of Genomics for Biodiversity (Langebio) was created as a new research unit in the CINVESTAV-IPN at Guanajuato; 
the objective of this centre is to achieve interdisciplinary genetic research focused on the Mexican biodiversity.

Table 3 Number of publication of Mexican universities and research centres, 1996-2008

\begin{tabular}{|c|c|c|}
\hline & Number of publications* & Organisations \\
\hline 1 & 818 & UNAM \\
\hline 2 & 553 & IPN \\
\hline 3 & 291 & UAM \\
\hline 4 & 278 & CONACYT \\
\hline 5 & 139 & IMSS \\
\hline 6 & 94 & U.A. de Nuevo León \\
\hline 7 & 72 & Universidad de Guadalajara \\
\hline 8 & 70 & IMP \\
\hline 9 & 64 & CIMMYT \\
\hline 10 & 51 & U.A. del Estado de Morelos \\
\hline 11 & 42 & U.A. del Estado de Coahuila \\
\hline 12 & 42 & Universidad de Guanajuato \\
\hline 13 & 21 & Inst. Tecnológico de Celaya \\
\hline 14 & 35 & Clínica Ruiz de Puebla \\
\hline 15 & 30 & Inst. Tecnológico de Veracruz \\
\hline 16 & 28 & ITESM \\
\hline 17 & 23 & Instituto Nacional de Cardiología \\
\hline 18 & 23 & U.A. de Baja California Sur \\
\hline 19 & 22 & U.A. de Sonora \\
\hline 20 & 22 & U.A. de Yucatán \\
\hline 21 & 21 & Instituto Nacional Ciencias de Médicas \\
\hline 22 & 19 & U.A. de San Luis Potosí \\
\hline 23 & 18 & Universidad Veracruzana \\
\hline 24 & 15 & U.A. de Querétaro \\
\hline Total & 2,791 & \\
\hline
\end{tabular}

Note: *This number includes the publications of the different schools, faculties and departments that belong to each organisation.

Source: Science-Metrix

Industrial applications and types of firms: in Mexico there are around 60 enterprises that perform activities related to the use and development of modern biotechnologies [Secretaría de Economía, (2010), p.41] $]^{14}$. The following paragraphs describe the characteristics of some of these firms based on the data collected. Table 4 shows the types of biotechnologies that have been adopted for the interviewed firms.

Most of the firms have adopted and currently use process biotechnologies (56.3\%); followed by cell and tissue culture and engineering, and others (37.5\% each one); proteins and molecules, and environmental biotechnologies ( $18.8 \%$ each one), 
while more complex biotechnologies such as DNA codification (12.5\%) and nano-biotechnologies $(6.3 \%)$ have been adopted by few firms ${ }^{15}$. These results show that very few firms in the sample have adopted modern biotechnologies; medium complex biotechnologies are more prevalent.

Table 4 Biotechnologies and their uses by firms in Mexico

\begin{tabular}{|c|c|c|c|c|c|c|c|c|c|c|}
\hline \multirow[t]{2}{*}{ Biotechnologies } & \multicolumn{4}{|c|}{ Use } & \multicolumn{2}{|c|}{ Production } & \multicolumn{2}{|c|}{$\begin{array}{c}\text { Product/process } \\
\text { development }\end{array}$} & \multicolumn{2}{|c|}{$\begin{array}{l}\text { Environmental } \\
\text { reasons }\end{array}$} \\
\hline & Yes & $\%$ & No & $\%$ & Yes & $\%$ & Yes & $\%$ & Yes & $\%$ \\
\hline DNA codification & 2 & 12.5 & 14 & 87.5 & 2 & 100 & 2 & 100 & 1 & 50 \\
\hline $\begin{array}{l}\text { Proteins and } \\
\text { molecules }\end{array}$ & 3 & 18.8 & 13 & 81.3 & 3 & 100 & 3 & 100 & 0 & 0 \\
\hline $\begin{array}{l}\text { Cell and tissue } \\
\text { culture and eng. }\end{array}$ & 6 & 37.5 & 10 & 62.5 & 5 & 83.3 & 5 & 83.3 & 0 & 0 \\
\hline $\begin{array}{l}\text { Process } \\
\text { biotechnologies }\end{array}$ & 9 & 56.3 & 7 & 43.8 & 9 & 100 & 6 & 66.7 & 3 & 33.3 \\
\hline Sub-cell organisms & 1 & 6.3 & 15 & 93.8 & 1 & 100 & 1 & 100 & 0 & 0 \\
\hline Bioinformatics & 0 & 0 & 16 & 100 & 0 & 0 & 0 & 0 & 0 & 0 \\
\hline Nano-biotechnology & 1 & 6.3 & 15 & 93.8 & 0 & 0 & 1 & 100 & 0 & 0 \\
\hline Environment biotech & 3 & 18.8 & 13 & 81.3 & 2 & 66.7 & 2 & 66.7 & 0 & 0 \\
\hline Other (enzymes) & 6 & 37.5 & 10 & 62.5 & 3 & 50 & 4 & 66.7 & 3 & 50 \\
\hline
\end{tabular}

Source: Own elaboration

Regarding the purpose of using biotechnologies, all firms in the sample use biotechnologies in their production and product development processes. In the case of nano-biotechnologies, these are only used for product development (Table 4). Very few firms are dedicated to produce biotechnology products per se, rather, most of them use biotechnologies to improve production processes of products that are already in the market (e.g., insulin, human growth hormone, enzymes). The firms that participated in this study produce goods and services that can be categorised into the following industries: agriculture, environment, food processing and human health.

Characteristics such as age, years using biotechnologies, and participation in foreign markets were used to identify the types of biotechnology users in Mexico (Table 5). Two types of users ${ }^{16}$ were identified: The first one involves those firms that were established since the 1970s, which in some cases have had products in the market for around 30 years and have used biotechnologies since then. These firms also have foreign trade activities. Given these characteristics, one can intuitively suggest these firms have improved their biotechnology processes in order to maintain their position in national and international markets. In addition, the accumulation of capabilities has allowed these firms to adopt modern biotechnologies to enter in new markets with new products to the firm (e.g., generics biopharmaceuticals) and improving production processes. The second type of users is characterised by relatively young enterprises - they were founded since the 1990s, which are small and medium-size and they do not have activities in foreign markets. It seems these firms are seeking to improve their processes and products and move on their position in the domestic market; and they have few years adopting biotechnologies. 
Table 5 Characteristics: sector, age, experience, size, and trade

\begin{tabular}{lcccc}
\hline Sector & $\begin{array}{c}\text { Year of } \\
\text { foundation or } \\
\text { restructure }\end{array}$ & $\begin{array}{c}\text { Number of years } \\
\text { using biotech. } \\
(2009)\end{array}$ & $\begin{array}{c}\text { Number of } \\
\text { employees } \\
(2008)\end{array}$ & Export \\
\hline Human health & 1999 & NA & 500 & No \\
Agriculture & 1970 & 20 & 900 & Yes \\
& 1990 & 19 & 108 & Yes \\
& 1976 & 33 & 94 & Yes \\
& 2004 & 5 & 16 & No \\
Food & 2003 & 6 & 42 & No \\
processing & 1995 & 12 & 3 & No \\
& 1990 & 15 & 110 & Yes \\
Environment & 1992 & 23 & 14 & Yes \\
& 1986 & 35 & 34 & Yes \\
& 1974 & 10 & 108 & Yes \\
& 1986 & 10 & 165 & No \\
& 1998 & 14 & 18 & No \\
& 1999 & 2 & 21 & Yes \\
& 1996 & 13 & 14 & No \\
\hline
\end{tabular}

Source: Own elaboration

In sum, based on the information about the purposes for using biotechnologies (Table 4) and the firms' characteristics -age, experience using biotechnologies, and foreign trade (Table 5): the adoption of biotechnologies in Mexico seems to be carried out by enterprises that are already in the market and look for improvements on their processes or lines of businesses at national and international markets.

\subsubsection{Linkages}

The development and commercialisation of biotechnology products often require the collaboration of different organisations. The firms in the sample recently have started to establish collaboration agreements. In $2005,31.3 \%$ of these firms established collaborations, after 2005 this percentage has increased to $68.8 \%$.

In general terms, the most active firms collaborating are those in the human health sector followed by those in agriculture, environment, and finally food processing. Firms in the human health industry collaborate with a wide range of partners: other biotechnology firms, pharmaceutical companies, and enterprises other than biotech or pharmaceutical, academic organisations, and government laboratories. The main motives to collaborate with other biotechnology firms are access to scientific advances and adoption of new knowledge (e.g., to conduct R\&D, access others' knowledge and skills, and access to intellectual property). Collaboration with other companies is aimed to access markets and production/manufacturing. Firms in the agricultural sector collaborate with other biotechnology enterprises, academic institutions and government laboratories. The main motives to collaborate are to conduct R\&D, to access others' knowledge and 
skills, and to access intellectual property. Firms in the environment sector collaborate mainly with academic organisations to conduct R\&D activities. Finally, firms in the food processing sector collaborate with other organisations to have access to production or manufacturing activities.

Excluding firms in the environment sector, the firms in the sample also have established collaborations with organisations located in other countries. Again, enterprises using biotechnologies in the human health sector have been more active collaborating with other biotechnology firms located in developed countries (e.g., the United States and European countries). Motives for these collaborations are to conduct R\&D activities, regulatory affairs, production/manufacturing, and access to market. Access to capital, patents and other intellectual property were not motives for collaboration with foreign agents. Firms in the agriculture and food processing sectors also collaborate with biotechnology enterprises.

It seems that medium and large enterprises with higher technological and managerial capabilities are more active in the adoption of modern biotechnology and more able to establish collaboration agreements with international partners. In order to test this proposition, biserial tests were conducted to evaluate the relationship between

- the firm size and biotechnology capabilities

- $\quad$ size biotechnology and international collaboration

- biotechnology capabilities and international collaborations.

The biserial correlations produce significant results for each pair of variables: size and years using biotechnology $\left(r_{b}=0.4797, \mathrm{p}<0.10\right)$, biotechnology size and external collaboration, $\left(r_{b}=0.4423, \mathrm{p}<0.010\right)$, and years using biotechnology and external collaboration $\left(r_{b}=0.4808, \mathrm{p}<0.010\right)$.

This pattern of collaboration confirms the need to seek complementary knowledge with other actors. Also, an important issue emerges. Even if the local institutional framework does not offer a well-coordinated support, firms try to use it no matter how limited it is, and when they need extra help they look for collaboration abroad. For this collaboration to take place Mexican firms need to have a certain absorptive capacity that is present in some large and medium established companies but that is absent in small ones. Thus, the latter are at disadvantage because they are stuck with only the resources available from local institutions.

Although there are knowledge-creating organisations and enterprises using biotechnologies, there are organisations and institutions missing or with little presence in Mexico: funding organisations: commercial banks and public equity market have a small participation in supporting innovative initiatives, especially of those coming from small and medium enterprises: "During the last ten years, the industry has predominately have been governed by foreign investors who primarily focus on late-stage investments" [Charvel et al., (2006), p.311]. The venture capital industry in Mexico is in its infancy phase; private and institutional players do not have incentives to take high risks (Charvel et al., 2006; Lavca, 2010). Efforts to foster scientific research: although the Mexican government has implemented policies to improve domestic science and technology, these efforts are falling short: the government investment in R\&D activities respect to the GDP is only $0.37 \%(\mathrm{OECD}, 2011 \mathrm{a})$ (see Table 6). Intellectual property rights: The Mexican 1991 'Law for the Promotion and Protection of Industrial Property' provides IPR for a 
broad range of inventions, including chemicals, plant varieties and biotechnological processes. Although Mexican intellectual property law is based on international standards ${ }^{17}$ there is a lack of mechanisms to motivate the appropriation of scientific knowledge (Shadlen, 2009).

Table 6 GERD in selected countries, 2003-2008

\begin{tabular}{lcccccc}
\hline Country & 2003 & 2004 & 2005 & 2006 & 2007 & 2008 \\
\hline Canada & 2.04 & 2.07 & 2.05 & 1.97 & 1.90 & 1.84 \\
Germany & 2.52 & 2.49 & 2.49 & 2.53 & 2.53 & NA \\
Korea & 2.49 & 2.68 & 2.79 & 3.01 & 3.21 & 3.36 \\
USA & 2.61 & 2.54 & 2.57 & 2.61 & 2.67 & 2.79 \\
UK & 1.75 & 1.68 & 1.73 & 1.75 & 1.78 & 1.77 \\
Brazil & 0.96 & 0.90 & 0.97 & 1.0 & 1.10 & 1.13 \\
China & 1.13 & 1.23 & 1.34 & 1.42 & 1.44 & NA \\
India & 0.80 & 0.79 & 0.84 & 0.88 & 0.87 & 0.88 \\
Mexico & 0.40 & 0.40 & 0.41 & 0.39 & 0.37 & NA \\
South Africa & 0.80 & 0.86 & 0.92 & 0.95 & NA & NA \\
\hline
\end{tabular}

Note: Not available (N.A.)

Source: OECD (2011b)

\section{Conclusions}

In spite of the underdeveloped Mexican system of innovation, there are HEI, PRC and enterprises looking for developing and adopting modern biotechnologies. The creation and revamp of research centres focused on biotechnologies show some scientific production that potentially can be the basis of a knowledge-producing part of a biotechnology innovation system. Some firms are incorporating biotechnologies to their processes, and the potential benefit of using biotechnologies is reflected in the variety of industries adopting them. However, even though there exist an important science base, a potential use of biotechnologies, and some firms are actually using them, the links between these actors - universities and firms - remain poor.

Even though some policies have been put in place to foster scientific research and encourage collaborations in Mexico, the institutional framework is still very underdeveloped, which is reflected in the system of innovation. This framework lacks the presence of some important agents, like venture capital, which is crucial to finance the uncertain biotechnology developments. This situation prevents the surge of start-up firms that usually require strong financial support given the uncertainty they face. Therefore, the few Mexican firms that actually attempt to adopt biotechnologies do so in a limited institutional framework.

In spite of these limitations, Mexican firms have established collaboration with some local organisations like other biotechnology firms, universities and firms in other sectors. The reasons for these collaborations are the acquisition of new knowledge and skills. Some of the firms, the large/medium-size with experience, overcome the limitations of the Mexican environment and collaborate with foreign agents. This overall panorama 
reflects the urgent need to promote policies in order to improve both, the quality of research and the variety of agents to adopt biotechnologies. In addition, the Mexican case shows that the government has to evaluate which kinds of firms are adopting modern biotechnologies in order to create appropriate organisations and institutions to foster innovation.

\section{References}

Audretsch, D.B. (2001) 'The role of the small business in U.S. biotechnology clusters', Small Business Economics, Vol. 17, Nos. 1-2, pp.1-10.

Beuzekom, B. and Arundel, A. (2009) Biotechnology Statistics, OECD Publishing, Paris.

Bolívar, Z.F. et al. (Coord.) (2002) Biotecnología moderna para el desarrollo de México en el siglo $X X I$. Retos y oportunidades, CONACYT/FCE, Mexico.

Casas, R., de Gortari, R. and Santos, M.J. (2000) 'The building of knowledge spaces in Mexico: a regional approach to networking', Research Policy, Vol. 29, No. 2, pp.225-241.

Charvel, R. (2007) 'A comprehensive look at private equity industry in Mexico (1990-2006)', The Journal of Private Equity, Vol. 10, No. 4, pp.42-53.

Charvel, R., Gonzalez, L.F. and Olivas, D. (2006) 'The unfulfilled need of venture capita in Mexico', International Journal of Entrepreneurship and Innovation Management, Vol. 5, Nos. 4/5, pp.303-325.

Chiaroni, D. and Chiesa, V. (2006) 'Forms of creation of industrial clusters in biotechnology', Technovation, Vol. 26, No. 9, pp.1064-1076.

Cimoli, M. (2000) Developing Innovation Systems: Mexico in a Global Context, Continuum, New York-London.

Cockburn, I.M. and Stern, S. (2010) 'Finding the endless frontier: lessons from the life science innovation system for technology policy', Capitalism and Society, Vol. 5, No. 1, pp.1-48.

Cohen, W.M. and Levinthal, D.A. (1990) 'Absorptive capacity: a new perspective in learning and innovation', Administrative Science Quarterly, Vol. 35, No. 1, pp.128-152.

Cooke, P. (2007) Growth Cultures: The Global Bioeconomy and its Bioregions, Routledge, London.

Cooke, P. and Morgan, K. (1998) The Associational Economy: Firms, Regions, and Innovation, Oxford (England); Oxford University Press, New York.

Corona, J.M. (2006) Human Capital Formation: The Role of Science and Technology Policy. A Case Study in the Mexican Biotechnology Sector, PhD thesis, Manchester Business School.

Dutrénit, G., Capdeville, M., Alcantar, J.M.C., Anyul, M.P., Santiago, F. and Vera-Cruz, A.O. (2010) El Sistema Nacional de Innovación Mexicano, Instituciones, Políticas, Desempeño y Desafios, UAM-Textual, Mexico.

Fan, P. (2011) 'China and India: innovation capability and economic development', Economic Change and Restructuring, Vol. 44, Nos. 1-2, pp.49-73.

Fuchs, G. and Krauss, G. (2003) 'Biotechnology in comparative perspective', in Fuchs, G. (Ed.): Biotechnology in Comparative Perspective, pp.1-13, Routledge, London.

Kenney, M. (1986) Biotechnology: The University-Industry Complex, Yale University Press, New Haven.

Latin America Venture Capital Association (Lavca) (2010) 'Scorecard 2010', pp.20-21 [online] http://lavca.org/2010/04/21/2010scorecard/ (accessed 20 September 2011).

Lundvall, B.A. (1992) National System of Innovation: Towards a Theory of Innovation and Interactive Learning, Pinter, London.

Nature (2005) 'Outlook: India', Nature, Vol. 436, No. 705, pp.478-498. 
Nature Biotechnology (2004) 'Open secrets', Nature Biotechnology, Vol. 22, Nos. 12s, p.DC1, doi:10.1038/nbt1204supp-DC1.

Nature Biotechnology (2010a) 'Special report: biotech in China', Nature Biotechnology, February [online] http://www.nature.com/nbt/advertorial/china/index.html (accessed 12 September 2011).

Nature Biotechnology (2010b) 'Special report: biotech in India', Nature Biotechnology, November [online] http://www.nature.com/nbt/advertorial/india/index.html (accessed 12 September 2011).

Nelson, R.R. (1993) National Innovation System: A Comparative Analysis, Oxford University Press, New York.

Nelson, R.R. (2000) 'National innovation systems', in Ács, Z.J. (Ed.): Regional Innovation, Knowledge and Global Change, pp.11-26, Pinter, London.

Niosi, J. (2010) Building National and Regional Innovation Systems: Institutions for Economic Development, Edward Elgar, Cheltenham, UK; Northampton, MA.

Niosi, J. and Bas, T.G. (2003) 'Biotechnology megacentres: Montreal and Toronto regional systems of innovation', European Planning Studies, Vol. 11, No. 7, pp.789-804.

Niosi, J. and Reid, S.E. (2007) 'Biotechnology and nanotechnology: science-based enabling technologies as windows of opportunity for LDC?', World Development, Vol. 35, No. 3, pp.426-438

Niosi, J., Bas, T.G. and Zhegu, M. (2005) Canada's Regional Innovation Systems: The Science-based Industries, McGill-Queen's University Press, Montreal.

Nonaka, I. (1994) 'A dynamic theory of organizational knowledge creation', Organizational Science, Vol. 5, No. 1, pp.14-37.

North, D.C. (1990) Institutions, Institutional Change and Institutional Performance, Cambridge University Press, Cambridge.

OECD (2009a) Reviews of Innovation Policy, OECD Publishing, Mexico [online] http://www.oecd-ilibrary.org/science-and-technology/oecd-reviews-of-innovationpolicymexico-2009_9789264075993-en (accessed 28 July 2010).

OECD (2009b) Reviews of Regional Innovation: 15 Mexican States, OECD Publishing [online] http://www.oecd.org/dataoecd/45/1/42644342.pdf (accessed 28 July 2010).

OECD (2011a) Factbook [online] http://www.oecd-ilibrary.org/economics/oecd-factbook (accessed 17 September 2011).

OECD (2011b) [online] http://www.oecd-ilibrary.org/science-and-technology/gross-domesticexpenditure-on-r-d_2075843x-table1 (accessed 28 September 2011).

Oliver, M. (2001) 'Strategic alliances and the learning life cycle of biotechnology firms', Organization Studies, Vol. 22, No. 3, pp.467-489.

Pichaud, B.S. (2002) 'Outsourcing in the pharmaceutical manufacturing process: and examination of the CRO experience', Technovation, Vol. 22, No. 2, pp.81-90.

Pisano, G. (2006) Science Business: The Promise, the Reality, and the Future of Biotech, Harvard Business School Press, Boston, Mass.

Possani, L.D. (2003) 'The past, present and future of biotechnology in Mexico', Nature Biotechnology, Vol. 21, No. 5, pp.582-583.

Powell, W. (1990) 'Neither market nor hierarchy: network forms of organizations', Research in Organizational Behavior, Vol. 12, No. 4, pp.295-336.

Powell, W., Koput, K., and Smiyth-Doerr, L. (1996) 'Interorganizational collaboration and the locus of innovation: networks of learning in biotechnology', Administrative Science Quarterly, Vol. 41, No. 1, pp.116-145.

Prevezer, M. (2008) 'Technology policies in generating biotechnology clusters: a comparison of China and the US', European Planning Studies, Vol. 16, No. 3, pp.359-374. 
Pyka, A. and Saviotti, P. (2000) 'Innovation networks in the biotechnology-based sectors', in Pyka, A. and Kuppers, G. (Eds.): Innovation Networks. Theory and Practice, pp.75-107, Edward Elgar Publishing, Northhampton, MA.

Rothaermel, F.T. and Deeds, D.L. (2004) 'Exploration and exploitation alliances in biotechnology: a system of new product development', Strategic Management Journal, Vol. 25, No. 3, pp.201-231.

Secretaria de Economía (Ministry of Economy) (2010) Sistema Integral de Innovación para Mexico [online] http://www.economia.gob.mx/swb/es/economia/p_Industria_y_Comercio (accessed 17 September 2010).

Shadlen, K.C. (2009) 'The politics of patents and drugs in Brazil and Mexico: the industrial bases of health policies', Journal of Comparative Politics, Vol. 42, No. 1, pp.41-58.

Sharif, N. (2006) 'Emergence and development of the national innovation system concept', Research Policy, Vol. 35, No. 5, pp.745-766.

Singh, S. (2010) Handbook of Business Practices and Growth in Emerging Markets, Scientific, Hackensack, NJ.

Smith-Doerr, L. and Powell, W. (2005) 'Networks and economic life', in N. Smelser and Swedberg, R. (Eds.): Handbook of Economic Sociology, pp.379-402, Princeton University Press, Princeton.

Teece, D.J., Pisano, G. and Shuen, A. (1997) 'Dynamic capabilities and strategic management', Strategic Management Journal, Vol. 18, No. 7, pp.509-533.

Wolson, R.A. (2007) 'The role of technology transfer offices in building the South African biotechnology sector: an assessment of policies, practices and impact', Journal of Technology Transfer, Vol. 32, No. 4, pp.343-365.

Zahra, S. and George, G. (2002) 'Absorptive capacity: a review, reconceptualization, and extension', Academy of Management Review, Vol. 27, No. 2, pp.185-203.

Zucker, L.G., Darby, M.R. and Armstrong, J. (1998) 'Geographically localized knowledge: spillovers or markets?’, Economic Inquiry, Vol. 36, No. 1, pp.65-86.

\section{Notes}

1 There is an extensive range of biotechnology applications - from empirical application of yeast and bacteria for food processing and selective animal breeding to new techniques such as genetic engineering, recombinant DNA, genetic therapy, monoclonal antibodies, and bioremediation.

2 Adoption refers to the action of use biotechnologies to manufacture or develop products and services.

3 "An emerging market refers to a developing market economy with low-to-middle per capita income. Countries in this category are usually undertaking a process of economic development and reform... they are in the process of moving from close economies to more open economies... they experience rapid growth in both local and foreign investment" [Singh, (2010), p.1]. A variety of agencies have proposed different lists of emerging countries that include Argentina, Brazil, Chile, China, Colombia, Czech Republic, Egypt, Hungary, India, Indonesia, Malaysia, Mexico, Morocco, Peru, Philippines, Poland, Saudi Arabia, Singapore, South Africa, South Korea, Russia, Taiwan, Thailand, and Turkey.

4 An institutional framework represents the "ability to the government to design and implement appropriate economic policies" [Niosi and Reid, (2007), p.426].

5 Mexico is among the eleven largest pharmaceutical markets worldwide, the seventh pharmaceutical emerging markets, and the second market in Latin America, after Brazil. Information retrieved from www.pharmavoice.com). According to the International Service for the Acquisitions of Agri-biotech Applications (ISAAA), with data for 2009, Mexico occupies the 15 th place among the countries that cultivated OGM $(\sim 100,000$ ha. $)$. Information retrieved from http://www.agrobiomexico.org.mx/documentos.htm (September 23, 2011). 
6 Knowledge is based on the interaction among individuals; therefore, organisational knowledge can be understood as a process in which the knowledge created by individuals is amplified 'organisationally', and crystallized as a part of the organisation's knowledge network (Nonaka, 1994).

7 The PECITI 2008-2012 mentions biotechnology as a strategic field for the economy, and proposes the creation of some technology parks focused on biotechnology in Monterrey, Nuevo León and Cuernavaca, Morelos.

8 According to the Ministry of Economy, in Mexico there are around 60 enterprises that use and develop modern biotechnologies (Secretaría de Economía, 2010). However, there is not a clear identification of those firms. I identified 58 enterprises by searching on the Internet.

9 This questionnaire was inspired on the Statistic Canada biotechnology questionnaire, and is used in a larger project including Argentina, Brazil, Chile, China, India, Singapore and South Korea directed by Jorge Niosi and supported by FQRSC.

10 For example, the S\&T Laws 1999, 2002 and 2009 which are focused on mechanisms to improve the interactions and coordination between agents; the main objective of the S\&T Special Programme 2002-2006 (PECYT in Spanish) is to guide the design and implementation of public policy to improve the scientific and technological system; and the ST\&I Special Programme 2007-2012 (PECiTI), whose objective is to reinforce the PECYT 2002-2006.

11 These programmes are: more support for the national system of researchers and post-graduate scholarships; tax credits (focused on small and medium enterprises (SME), new technologies, and competitiveness improvement); CONACYT's mixed funds (FOMIX); FORDECYT (focused on S\&T promotion at sub-national levels); and AVANCE (focused on fostering businesses based on scientific and technological developments).

12 Former Nitrogen Fixation Research Centre (CIFN), see http://www.ccg.unam.mx.

13 See http://www.inmegen.gob.mx. This centre is provisionally located in Mexico City; in the short term it will move to Cuernavaca, Morelos where the Biotechnology Institute and the CCG, both of the UNAM, are also established.

14 According to the Secretariat of Economy in Mexico there are around 300 firms using biotechnologies in six different industries: agriculture, food processing, environment, fermentation, animal health, pharmaceutical, and services that use biotechnologies. However, it is not clear if these firms are using modern biotechnologies (Secretaría de Economía, 2010).

15 Bioinformatics were not used for the firms in the sample.

16 A non-parametric test for small samples (Mann-Whitney) was conducted to verify the difference between the two group of enterprises $(\mathrm{n} 1=6, \mathrm{n} 2=10)$. The two groups are not significantly different in terms of the age $(U=12, p>0.05$, two tailed test). The difference between the two groups is significant in terms of the number of years using biotechnologies (experience) $(\mathrm{U}=11, \mathrm{p}<0.05$, two tailed test); and in terms of export activities $(\mathrm{U}=8$, $\mathrm{p}<0.05$, two tailed test).

17 The incorporation to the North American Free Trade Agreement (NAFTA) and the WTO Agreement on Trade-Related Aspects of Intellectual Property Rights (TRIPS) obligated Mexico to implement international standards for the protection of intellectual property. 